\title{
Administrative Costs of Environmental Taxes in the Czech Republic
}

\author{
Lenka Hyklová*
}

\begin{abstract}
:
Administrative costs of environmental taxes are a more and more discussed topic. These costs should be understood as part of the tax entity, so by the tax administrator. The aim of this thesis is to evaluate the administrative costs of environmental taxes in the Czech Republic from the perspective of the tax administrator. These costs are analyzed by customs offices, Ministry of Finance, General Directorate. In the Czech Republic there are no statistics to this problem, that before was for research interviewing form. In this paper there excise taxes and environmental taxes are compared with an emphasis on administrative costs of these taxes. The effectiveness of both taxes are compared. The effectiveness of environmental taxes is not as high as the effectiveness of excise taxes.
\end{abstract}

Key words: Administrative costs; Environmental taxes; Excise taxes.

JEL classification: $\mathrm{H} 23$.

\section{Introduction}

The Czech Republic's accession to the European Union entailed a lot of changes. One of them was the binding adoption of Directive 2003/96/EC. The Czech Republic was granted an exemption by the European Union and the introduction of environmental taxes was thus postponed until 2008. Široký (2008) in his book Tax theory with practical application points to the first environmental taxes in the Czech Republic. He describes taxes on electrical sources of radiation, mineral oils, coal and motor vehicles. Pigou (1928) was the first man, who described environmental taxes. He describes the problem with negative externalities. Dracea, Calugaru, and Cristea (2008) studied the establishing of an optimal tax level which has an effect of decreasing the overall cost of a negative externality. Their conclusion is: The environmental taxes should be introduced over the externalities source (report directly over emissions or environmental services).

The rate of environmental taxes was named by Pigou - pigovian rate. Bovenberg and Goulder (2002) found the optimal level of environmental taxes. They compare

Lenka Hyklová; University of Economics, Prague, Faculty of Finance and Accounting, Department of Public Finance, W. Churchill Sq. 4, 13067 Prague, Czech Republic, <L-Martinkova@seznam.cz>.

The contribution is processed as an output of the research project Public finance in the Czech Republic and the EU registered by the Internal Grant Agency of University of Economics, Prague under the registration number F1/1/2016. 
Hyklová, L.: Administrative costs of environmental taxes in the Czech Republic.

optimal taxation with the pigovian rate and conclude that the optimal tax should be lower.

The introduction of environmental taxes brought about a variety of concerns. The largest one was the fear of a loss of competitiveness at the level of individual states and an international comparison (Ekins 2007, Andersen 2007). Based on the ex post analysis of the introduction of environmental taxes, assessed by Zimmermannová and Menšík (2013), that the introduction of environmental taxes had no major impact on competitiveness reduction. Ex post analysis is dealt with also by Jílková, Vítek, Pavel, Slavík (2006), who focus on the administrative and induced costs of the charges collected for environmental protection in the Czech Republic.

Ex ante analysis of environmental taxes in the Czech Republic was dealt with by Šauer and Vojáček (2009). They point out that the private sector does not perceive that because of the introduction of environmental taxes there is a reduction in income tax. This is one of the indicated positives of the introduction of environmental taxes, referred to as the theory of double benefit, double dividend. This is discussed, for example, by Szomolányiová (2002). Theory of double dividend, described by Patuelli, Nijkamp and Pels (2005), who analyze environmental tax reform. They use meta-analytical synthesis. The conclusion is that their analysis confirms positive effect of tax policy when employment is used (the case theory of double dividend). On other side, Mongersten (1996), describes in a paper, that environmental tax does not always yield a double dividend in the additional sources of government revenue. Still, Mongersten points out that taxes are less costly than other measures to reduce environmental pollution.

The administrative costs of taxation are understood by the general public as the costs borne by the public sector. These are the costs associated with tax collection. Kubátová (2010) includes in this group all costs associated with collection and control activities and the costs related to the acquisition of information. Thus the defined costs are referred to as direct costs. On the other hand, there are indirect costs, also known as induced costs. These costs are borne by the private sector. These taxes are discussed in a paper by Pavel and Vítek (2010). In their analysis they have pointed out that the Czech Republic does not differ much from the results of foreign entities. Hruška, Dvořáková (2012) investigated the informational and motivational role of the state in relation to businesses. They concluded that the information services were insufficient and did not facilitate the activities of the businesses. Environmental costs in the businesses are analyzed by Zimmermanová (2011), Carrera and Ianuzzi (1998) and Rogers and Kristof (2003). 
This paper deals with the effectiveness of environmental taxes according to the analysis of effectiveness on the part of the direct administrative costs. The aim is to identify and evaluate the effectiveness of the management of environmental taxes. Before the introduction of environmental taxes, a number of ex ante analyses took place.

\section{Administrative Costs of Environmental Taxes}

The method of simple calculation of the administrative costs associated with the collection, control, administration, but also with legislation and law-making was used to determine the administrative burden of environmental taxes on the part of the tax administrator. Analyzing administrative costs are very complicated. Offices and firms find it very difficult to calculate these costs. The optimal distribution administrative costs of an emissions tax is describe Stranlud and Chávez (2013). They say that political facet is very important factor, which exert influence over administrative costs. In this paper there are direct administrative costs used as wages of the relevant workers (legislative cost, cost of state administration, costs of tax administration). This paper does not consider the costs associated with statistical office, the judiciary services, etc. Operating costs of environmental taxes for these staffers are low and the offices are not able to quantify and separate them from others activities in the offices. So these costs are not comprised in this paper. Excise taxes are used from customs offices. There are taxes on tobacco, mineral oils, spirits, beer and wine.

The management of environmental taxes is dealt with in the Czech Republic by the customs administration authority. Legislation and law-making fall under the authority of the Ministry of Finance and the General Directorate of Customs. Part of the analysis was thus questioning ${ }^{1}$ the customs offices of the particular regions ${ }^{2}$, the Ministry of Finance and the General Directorate of Customs. The essence was to determine to what extent they are burdened by the administration associated with the collection and legislation of environmental taxes. For the purposes of assessment, the full-time equivalent employee (FTE) method was used. The wage, including social security and health insurance contributions, was selected as the main cost.

The Czech Republic has 14 regions, but 15 customs offices. In reply to the questions about environmental taxes and all the monitored administrative costs the Ruzyně customs office stated that it had not registered any entity subject to

\footnotetext{
1 It is necessary to allow for some distortions due to the fact that the administration is often intermingled with multiple taxes. Separate records of the administrative costs of environmental tax do not exist.

2 Pursuant to Act No. 106/1999 Coll., regarding the provision of information.
} 
environmental taxes. This office is engaged primarily in Václav Havel airport. All the collection is thus provided by the customs office Prague.

The customs offices for individual regions differ considerably in their costs of administration of environmental taxes. The administrative costs of the collection of environmental taxes are shown in Figure 1. The data are for the year 2016 and for all the customs office branches except the customs office Ruzyně. The difference between the individual regions is determined by the amount of salary in a given area and the number of workers who take care of this agenda. The greatest number of FTEs engaged in environmental taxes was in the customs offices in Zlín and Prague.

\section{Fig. 1 Administrative costs in the regions (in mil. CZK)}

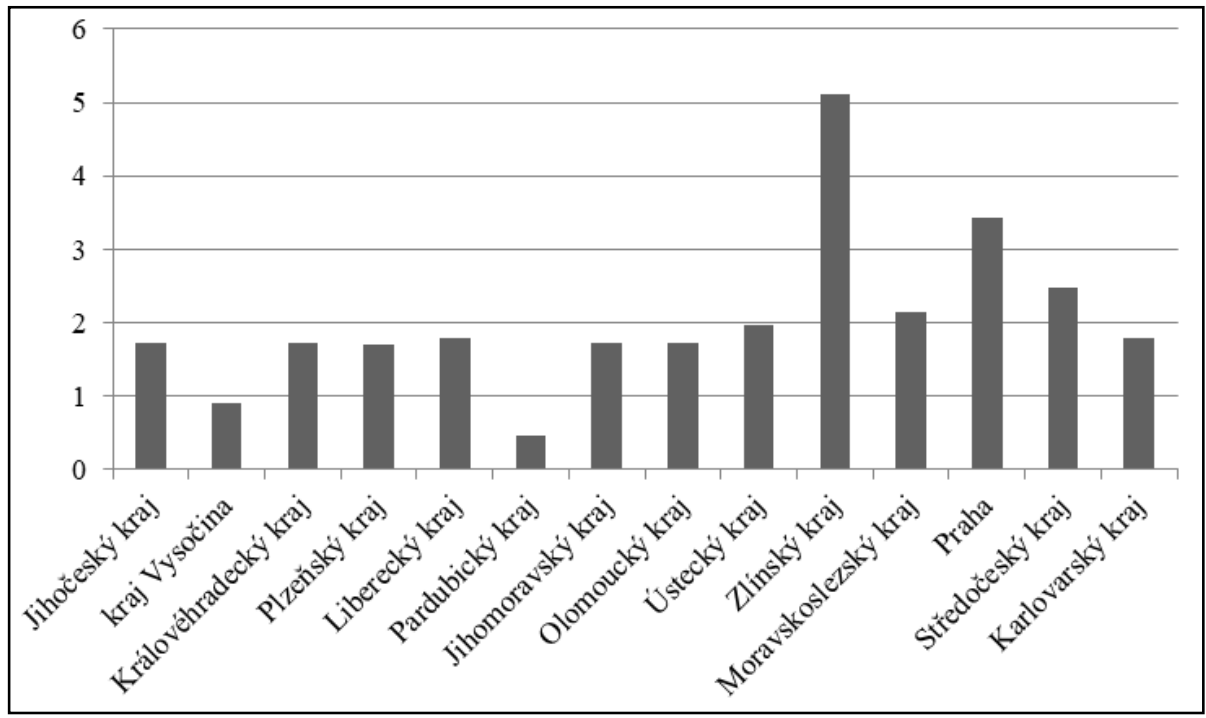

Source: Own processing (interview form).

\subsection{Environmental taxes and excise taxes}

The revenues of environmental and excise taxes are shown in Figure 2. The revenues of excise taxes for the year 2016 are not yet available (specifically, the tax on tobacco products), therefore only the years 2013-2015 are compared. The revenues of excise taxes during the reviewed years are still growing. In comparison with the revenues from environmental taxes, the excise taxes are up to 92\% higher. The reason is the greater scope of the taxable object and a higher tax burden. The data is used from the report from the customs office. 
Fig. 2 The revenues of environmental and excise taxes

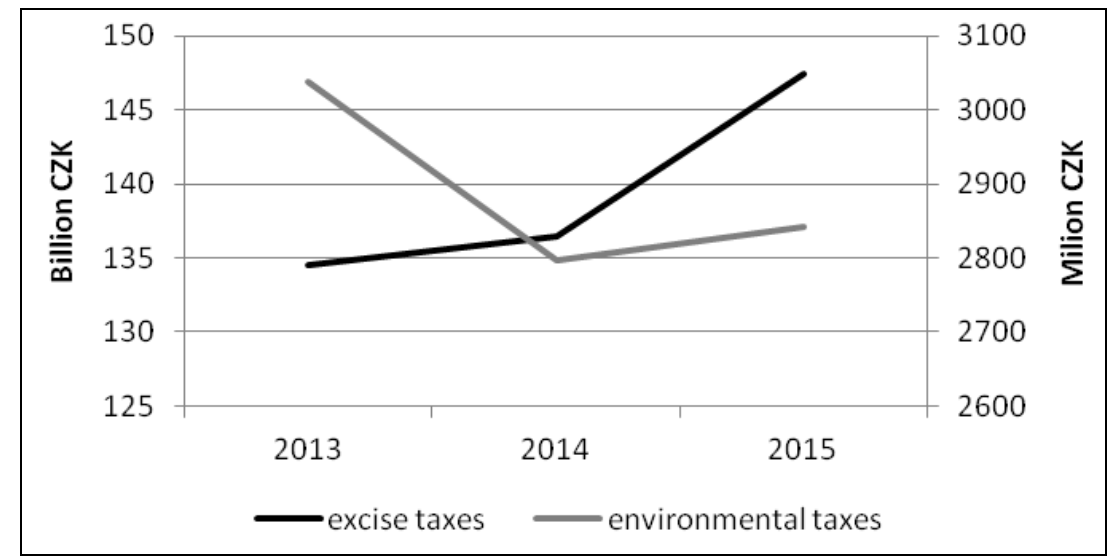

Source: Own processing (report on the activities of the customs office in these years).

The effectiveness of the administrative costs of the collection of environmental taxes (level of customs offices) is determined by the Equations

$$
A C=\frac{T C}{T R} * 100,
$$

Where AC is total costs per tax income percentage; TC means total administrative costs; TR is used for tax revenues (collection in cash terms).

Three years 2013-2015 were selected to determine the effectiveness. This range was chosen because it is very hard for the customs offices of the individual regions to estimate the earlier years. For the year 2016, not all the necessary data is available to determine the administrative burden of excise taxes and the income from tobacco products. The effectiveness was investigated for both the environmental taxes and the excise taxes of the customs office. The result is shown in Table 1. 
Hyklová, L.: Administrative costs of environmental taxes in the Czech Republic.

Tab. 1 Percentages of effectiveness of Environmental and excise taxes in the years 2013 - 2015

\begin{tabular}{llll}
\hline & $\mathbf{2 0 1 3}$ & $\mathbf{2 0 1 4}$ & $\mathbf{2 0 1 5}$ \\
\hline Environmental taxes & 0,84 & 0,94 & 0,97 \\
Excise taxes & 0,17 & 0,15 & 0,15 \\
\hline
\end{tabular}

Source: Own processing (interview form).

In comparison with excise taxes and their administrative demands, it is clear that the administrative burden of environmental taxes is greater. The main reason is the lower collection of environmental taxes in the reviewed years. Excise taxes have a broader object of tax and a greater tax burden than environmental taxes.

\subsection{Other administrative costs}

Other costs associated with environmental taxes are the costs of the Ministry of Finance and the General Directorate. These costs are associated with legislation and law-making ${ }^{3}$. The costs specified based on questioning are shown in Table 2. The total costs are determined by the FTE quantity engaged in the administrative costs of environmental taxes and the wages they receive. The costs are highest in 2013. This was due to the more demanding agenda. The FTE amount was 0.75 . Then, in subsequent years, only 0.25 . The salary assessment is determined by class 14 tariff.

The General Directorate is responsible for the relevant customs offices. The number of FTEs engaged in the costs related to legislation in 2013-2015 is 0.25. The tariff class corresponding to these employees is 8 .

The effectiveness of administrative costs in the form of legislative amendments is shown in Figure 3 and in Figure 4. The Figure 3 shows a comparison of the administrative costs from the perspective of legislation of the Ministry of Finance. Here it is clear that environmental taxes are again far less effective than excise taxes. The reason is the involved FTE quantity and wages including social and health insurance. The legislative regulation of environmental taxes is very small since 2008 (introduction).

3 Because of the questioning conducted at the turn of the year 2016/2017, no data were available for the year 2016; they will be prepared only for the closing of the year 2016. 
Fig. 3 The effectiveness of the Ministery of finance

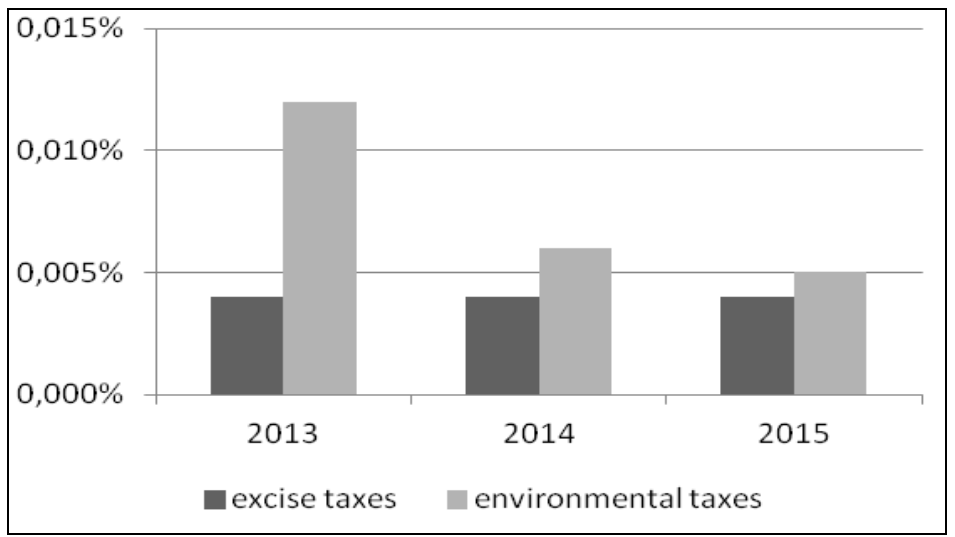

Source: Own processing (interview form).

The Figure 4 shows these administrative costs of the General Directorate of Customs for environmental and excise taxes. In this case, the effectiveness of environmental taxes is higher than the effectiveness of excise taxes. This is mainly influenced by the amount of the costs associated with excise taxes within the customs procedure. The General Directorate's costs of environmental taxes are almost zero. These taxes are patronized legislatively mainly by the Ministry of Finance.

\section{Fig. 4 The effectiveness of General Directorate of Customs}

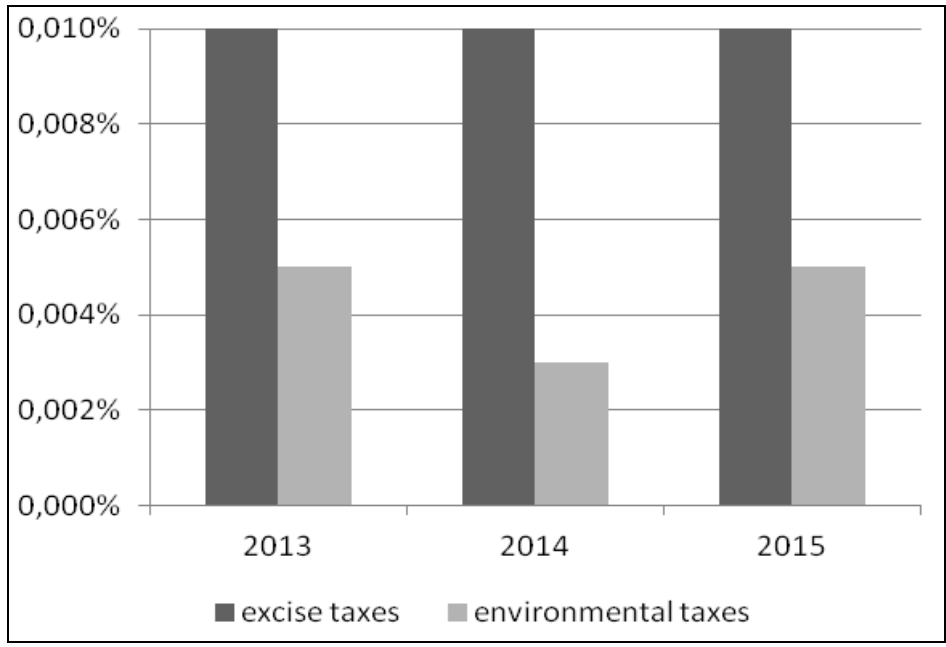

Source: Own processing (interview form). 
Hyklová, L.: Administrative costs of environmental taxes in the Czech Republic.

Tab. 2 Administrative costs (CZK) of Ministery of Finance and General directorate of Costums in the years 2013 - 2015

\begin{tabular}{llll}
\hline & $\mathbf{2 0 1 3}$ & $\mathbf{2 0 1 4}$ & $\mathbf{2 0 1 5}$ \\
\hline Ministry of Finance & 369960 & 169845 & 128460 \\
General Directorate of Customs & 139308 & 95369 & 146196 \\
\hline
\end{tabular}

Source: Own processing (interview form).

\subsection{The effectiveness of collection, control, management and legislation}

The following Figure shows a comparison of the effectiveness of environmental taxes with the effectiveness of taxes on consumption for the reference years 20132015. The costs include not only the cost of the collection, control and management of taxes, but also the cost of the legislation associated with these taxes. Accordingly, these are the cost of the customs offices, the Ministry of Finance and the General Directorate of Customs. The effectiveness of environmental taxes is significantly lower than the effectiveness of taxes on consumption. The reason is the minimum economies of scale and the very low collection. Environmental taxes fall under small taxes and must be assessed also in terms of their utility. It is also necessary to create an analysis on the part of taxpayers.

\section{Fig. 5 Comparison of the effectiveness}

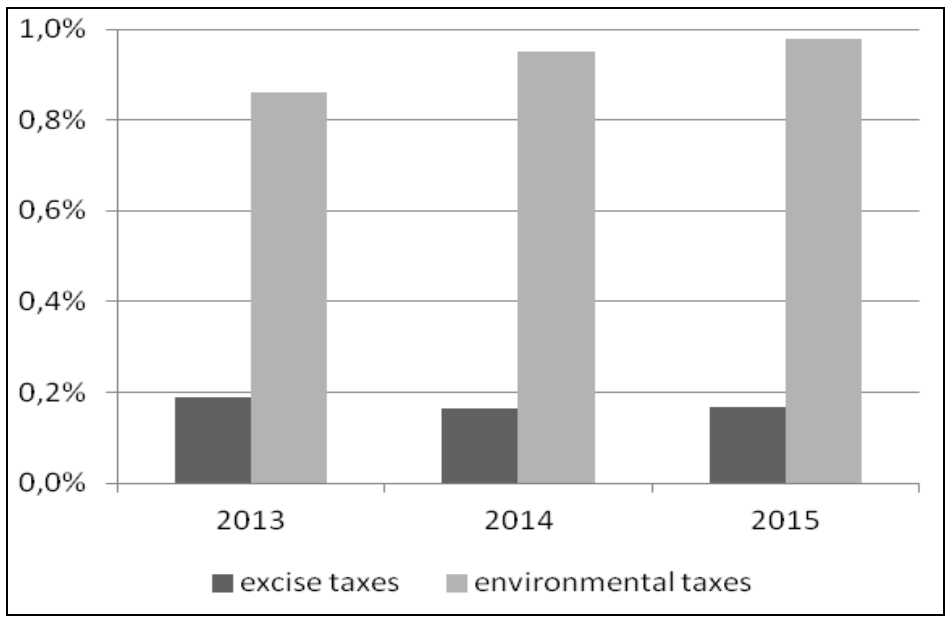

Source: Own processing (interview form). 


\section{Conclusion}

The administrative costs of environmental taxes should be seen from two sides. These are direct and indirect administrative costs. Direct costs are costs associated with managing and collecting environmental taxes, and indirect taxes are taxes that are borne by taxpayers. The paper deals with the direct costs, specifically the costs of customs administrations.

The effectiveness of environmental taxes is not as high as the effectiveness of taxes on consumption. The main reason is the relatively low collection in comparison with the count of employees in the individual customs offices in the Czech Republic. Another reason is the low economies of scale. The greatest economies of scale would be with one big tax, which, however, is not acceptable and effective.

A solution to increase the effectiveness of environmental taxes could be the inclusion of environmental taxes into taxes on consumption. This could lead to a decrease in administrative demands that are placed on the environmental costs. On the other hand, environmental taxes are small taxes, in which high collection cannot be expected. Thus, in comparison with the administrative costs, it can be expected that the effectiveness will be lower. For a complete analysis and assessment of whether it is appropriate to incorporate environmental taxes under the excise taxes, it is necessary to make an analysis on the part of the relevant entities. Here it can be expected that the administrative demands will not be so high. Environmental taxes are taxes that are not complicated and the system of their collection is relatively easy, so it can be expected that a smaller quantity of FTEs will be involved on the part of taxpayers.

Evans in his paper Studying the Studies: An overview of recent research into taxation evaluates the administrative costs of taxes very low. Very rarely administrative costs exceed $1 \%$ of tax revenues. Standford (1989) evaluate administrative costs as a percentage of tax revenue. He researches individual types of taxes. The values are between $0.12 \%$ and $1.53 \%$. He points out administrative costs of excise taxes. They are not as expensive as the administrative costs of income taxes. OECD studies (1988) note that income taxes and VAT are more expensive excise taxes.

Smulders and Vollenberg evaluate carbon excise as a new tax. They assess administrative cost of these taxes and results show that administrative costs are not so high, because administrative costs belong to administrative costs of energy taxes.

The values of administrative costs are described by Pavel and Vítek (2012). The reason for a not so high value of administrative cost environmental taxes is - in 
the case of energy and mineral oil taxes based on the principles of excise duties (small number of taxpayers, tax base oriented on market transaction, relatively simple construction of tax base).

Fullerton (1996), among other things, assesses administrative costs from the point of view of the state and the tax entity. He assesses that the administrative costs of the US government are not so high; costs are shifted to businesses.

\section{References}

Andersen, M. S., 2007. The Environmental Tax Reforms. COMETR WP 1 Policy Brief, Final COMETR Workshop, 21.3.2007, Bruxelles.

Bovenberg, A. L., Goulder, L. H., 2002. Environmental taxation and regulation, NBER Working Paper No. 8458. DOI: 10.3386/w8458.

Carrera, R. M.; Iannuzzi, A., 1998. Getting Started with Environmental Cost Accounting. Environmental Quality Management 1, 63-68. DOI: 10.1002/tqem. 3310080108.

Dracea, R., Calugaru, D. C., Cristea, M., 2008. The efficiency of the green taxes as instruments for environmental protection. Bulletin of the University of Agricultural Sciences 2, 110-115. Available from: <http://search.ebscohost.com/ login.aspx ?direct=true $\& \mathrm{db}=\mathrm{e} 5 \mathrm{~h} \& \mathrm{an}=37566902 \&$ scope $=$ site $>. \quad[11$ December 2016].

Ekins, P., 2007. The Effects of ETR on Competitiveness: Modelling with E3ME. COMETR WP 4 Policy Brief, Final COMETR Workshop, 21.3.2007, Bruxelles.

Evans, Ch., 2003. Studying the studies: An overview of recent research into taxation operating costs. eJournal of Tax Research 1, 64-92.

Fullerton, D., 1996. Why have separate environmental taxes? Tax policy and the Economy 10, 33-70. DOI: 10.1086/tpe.10.20061836.

Hruška, Z., Dvořáková, L., 2012. Výzkum vlivu a dopadu ekologického zdanění na podnikatelské subjekty $\mathrm{v}$ České republice. Trendy $\mathrm{v}$ podnikání 2012. Západočeská univerzita v Plzni, Plzeň, 1-8.

Jílková, J., Pavel, J., Vítek, L., Slavík, J., 2006. Poplatky k ochraně životního prostředí a jejich efektivnost. Eurolex Bohemia, Prague. ISBN 80-7379-002-5

Kubátová, K., 2010. Daňová teorie a politika. Wolters Kluwer, Prague.

Nobes, C., Parker, R. H., 2012. Comparative International Accounting. Pearson Education, London.

OECD, 1988. Taxing consumption. Organization for Economic Cooperation and Development, Parisp. 22-25 Available from: <http://www.oecd.org/std/ nahome.htm>. [9 October 2016]. 
Patuelli, R., Nijkamp, P., Pels, E., 2005. Environmental Tax Reform and the Double Dividend: A Meta-analytical Performance Assessment Ecological Economics 55, 564-583. DOI: 10.2139/ssrn.335720.

Pavel, J., Vítek, L., 2012. Transaction costs of environmental taxation: the administrative burden Handbook of Research on Environmental Taxation, 273282. DOI: $10.4337 / 9781781952146.00025$.

Pavel, J., Vítek, L., 2010. Environmental Tax Reform: Administrative and Compliance Cost of Energy Taxes in the Czech Republic. In SOARES, C. D. et al. (ed.): Critical Issues in Environmental Taxation. International and Comparative Perspectives. Vol. VIII. Oxford University Press, Oxford.

Pigou, A. C., 1928. A Study in Public Finance Macmillian and Co. 1928. DOI: $10.2307 / 2547800$.

Rogers, G., Kristof, J., 2003. Reducing Operational and Product Costs through Environmental Accounting Environmental Quality Management 3, 17-42. DOI: 10.1002/tqem.10071.

Sanford, C., Godwin, M., Hardwick P., 1989. Administrative and Compliance Costs of Taxation. Fiscal Publication, Bath. DOI: 10.1007/978-1-4615-1071-0_14.

Smulders, S., Vollebergh, H., 2001. Green taxes and administrative costs: The case of carbon taxation Behavioral and distributional effects of environmental policy, 91-130. DOI: 10.3386/w7298.

Stranlund, J., Chávez, C., 2013. Who should bear the administrative costs of an emissions tax? Journal of Regulatory Economics 44, 53-79. DOI: 10.1007/s11149013-9216-9.

Szomolányiová, J., 2002. Teoretická analýza př́nosů environmentálních daní Finance a úvěr, 371-379. ISSN 0015-1920.

Šauer, P., Vojáček, O., 2009. Environmental tax reform in the Czech Republic: results of a qualitative survey in businesses Mechanism of Economic Regulation 11, 31-41. DOI: 10.18267/j.efaj.91.

Široký, J. et al., 2008. Daňové teorie s praktickou aplikací C. H. Beck, Prague. ISBN 978-80-7400-005-8.

Zimmermannová, J., Menšík, M., 2013. Ex post analýza zavedení zdanění pevných paliv, zemního plynu a elektřiny Politická ekonomie 61, 46-66. DOI: 10.18267/j.polek.883. 
